\title{
STRENGTHENING LINGUISTIC AND EMOTIONAL INTELLIGENCE OF MADRASAH TEACHERS IN DEVELOPING THE QUESTION AND ANSWER METHODS
}

\author{
Syahraini Tambak \& Desi Sukenti \\ Universitas Islam Riau \\ Jl. Kaharuddin Nasution, No. 113, Marpoyan, Kota Pekanbaru Indonesia, 28284 \\ e-mail: syahraini_tambak@fis.uir.ac.id; desisukenti@edu.uir.ac.id
}

\begin{abstract}
Abstrak: Memperkuat Kecerdasan Linguistik dan Emosional Guru Madrasah dalam Mengembangkan Metode Tanya Jawab. Penelitian ini mengeksplorasi pengembangan metode tanya jawab dengan memperkuat kecerdasan linguistik dan kecerdasan emosional guru Madrasah Tsanawiyah. Jenis penelitian adalah korelasi yang dilakukan di Madrasah Tsanawiyah Negeri di seluruh Kota Pekanbaru. Analisis data menggunakan statistik inferensi dengan regresi linier. Penelitian ini menemukan bahwa kecerdasan linguistik dan kecerdasan emosional secara simultan berkontribusi kuat untuk mengembangkan kemampuan guru menggunakan metode tanya jawab dalam proses pembelajaran. Penguasaan kecerdasan linguistik dan kecerdasan emosional dapat mengembangkan keberhasilan guru-guru Madrasah Tsanawiyah menggunakan metode tanya jawab dalam pembelajaran. Kecerdasan emosional berkontribusi lebih tinggi daripada kecerdasan linguistik dalam mengembangkan keberhasilan guru-guru Madrasah Tsanawiyah dalam menggunakan metode tanya jawab selama pembelajaran.
\end{abstract}

\begin{abstract}
This research explores the development of a question and answer method by strengthening linguistic and emotional intelligence of Madrasah Tsanawiyah teachers. The type of research is the correlation carried out in the State Madrasah Tsanawiyah throughout Pekanbaru City where the subjects of this study are teachers in various fields of Islamic studies. Linguistic intelligence is predicted to be able to develop the success of teachers using the question and answer method, as well as emotional intelligence. The emotional intelligence contributes higher than linguistic intelligence in developing the success of Madrasah Tsanawiyah teachers in using question and answer methods during learning.
\end{abstract}

Keywords: linguistic, emotional intelligence, madrasah, Pekanbaru 
MIQOT Vol. 43 No. 1 Januari-Juni 2019

\section{Introduction}

The question and answer method is one of the important parts mastered by the teacher and becomes the key to successfully conveying the material to students in learning. So far in various literatures written and built that found a strong relationship between the success of a teacher in learning with the use of question and answer methods. It is as long as it is relevant to the character of the material, the learning environment, the type of learning of students in learning. ${ }^{1}$ The use of the question and answer method not only in the theoretical level is written in the design of learning preparation. The steps of the planned question and answer method must be applied according to the condition of the students, the characteristics of the material, and the creativity of the teacher. Teaching creativity is very urgent in the use of learning methods. ${ }^{2}$ Other theories state that all methods are very good to use as long as they are consistent with the characteristics of the material taught because they have strategic value to influence the course of learning activities. ${ }^{3}$

This research explores the development of the use of question and answer methods by strengthening linguistic intelligence and emotional intelligence in teachers of State Madrasah Tsanawiyah in the City of Pekanbaru. The question and answer method is very relevant to be developed by the teacher so that students can master the material easily. In various studies have been found the development of the use of question and answer methods in the learning process. Research by Satriani ${ }^{4}$ and Ahmad \& Tambak ${ }^{5}$ for example, revealed that the success of teachers using the question and answer method was formed by strengthening integral learning innovations. Helmi, in his research findings found that in supporting the success of Islamic Religious Education teachers using the question and answer method

${ }^{1}$ Armai Arief, Pengantar dan Metodologi Pendidikan Islam (Jakarta: Ciputat Pers, 2012), p. 39; Abuddin Nata, Perspektif Islam tentang Strategi Pembelajaran (Jakarta: Kencana Prenada Media Group, 2011), p. 68; Syahraini Tambak, 6 Metode Komunikatif Pendidikan Agama Islam (Yogyakarta: Graha Ilmu, 2014), p. 154; Zakiah Daradjat, Metodik Khusus Pembelajaran Agama Islam (Jakarta: Bumi Aksara, 1995), p. 56. Ahmad Tafsir, Metodologi Pembelajaran Agama Islam (Bandung: Remaja Rosdakarya, 2003), p. 134; Asrul dan Ja'far (ed.), Falsafah Pendidikan Islami: Menguak Nilai-nilai Pendidikan dalam Tradisi Islam (Medan: Perdana Publishing, 2016).

${ }^{2}$ Siti Aisyah Ginting, "A Facilitating Effective Teaching Through Learning Based on Learning Styles and Ways of Thinking," in Dinamika Ilmu: Journal of Education, Vol. 17, No. 2, 2017, p. 165-173.

${ }^{3}$ Syahraini Tambak, Pendidikan Agama Islam: Konsep Metode Pembelajaran PAI (Yogyakarta: Graha Ilmu, 2014), p. 56-78; Syaiful Bahri Djamarah \& Aswan Zain, Strategi Belajar Mengajar (Jakarta: Rineka Cipta, 2002), p. 187.

${ }^{4}$ Satriani, "Inovasi Pendidikan: Metode Pembelajaran Monoton ke Pembelajaran Variatif (Metode Tanya Jawab Plus)," in Jurnal Pendidikan Islam Iqra', Vol. 10, No. 1, 2016, p. 1-19.

${ }^{5} \mathrm{M}$. Yusuf Ahmad \& Syahraini Tambak, "Penerapan Metode Diskusi dalam Meningkatkan Hasil Belajar Murid pada Pelajaran Fiqh," in Al-Hikmah: Jurnal Agama dan Ilmu Pengetahuan, Vol. 5, No. 1, 2018, p. 64-84. 
required mastery of the application of the Silberman concept in PAI learning so that the learning activities of students develop optimally. ${ }^{6}$

The question and answer method used by state Madrasah Tsanawiyah teachers in the Pekanbaru City still tends to be less exploring the potential and understanding of students, even though a number of studies have been found to strengthen it. It's really a lot of learning material in the madrasah that demands being taught by the question and answer method. But in practice, the teacher of the madrasah tsanawiyah in this city is still less than optimal in carrying out the question and answer method in accordance with the steps. Learning atmosphere tends to be monotonous and the creativity of students is less explored. The question and answer method tends to run according to the taste of each teacher without heeding the steps according to the theory. As a result, students' mastery of the material being taught is less than optimal.

Thus, to develop the ability of teachers in the madrasah tsanawiyah to use the question and answer method, it is assumed that a solution is needed to strengthen linguistic intelligence and emotional intelligence to the fullest. Based on this, the research questions are how is the contribution of linguistic intelligence and emotional intelligence in developing the ability of teachers to use the question and answer method in the State Madrasah Tsanawiyah in Pekanbaru City? This research is very significant in exploring how the contribution of linguistic intelligence and emotional intelligence in developing the ability of teachers of Madrasah Tsanawiyah uses question and answer methods. This research will contribute to building the theory of the question and answer method in learning in madrasah. For lecturers, the subject of PAI Learning Methods in the Islamic Education Study Program can contribute significantly in preparing the syllabus, and developing lecture materials so that students can have good competence in the process of becoming a professional teacher. For Madrasah Head State Madrasah Tsanawiyah can be a reference in taking policies to develop teacher competencies to use question and answer methods in learning to produce quality students. For teachers of madrasah tsanawiyah, this research can contribute to improving the quality of use of the teacher question and answer method by strengthening linguistic intelligence and emotional intelligence in the learning process.

According to Campbell ${ }^{7}$ there are several characteristics of linguistic intelligence as follows; hear and respond to every sound, rhythm, color and various word expressions; imitate voice, language, reading, and writing from other people; learning through listening, reading, writing and discussion; listen effectively, understand, describe, interpret and remember what is said; read effectively, understand, summarize, interpret or explain, and remember

${ }^{6}$ Jon Helmi, "Penerapan Konsep Silberman dalam Metode Tanya Jawab pada Pembelajaran Pendidikan Agama Islam," in Al-Ishlah: Jurnal Pendidikan, Vol. 8, No. 2, 2016, p. 212-245.

${ }^{7}$ Linda Campbell, Multiple Intelligences: Metode Terbaru Melesatkan Kecerdasan (Depok: Inisiasi Press, 2002), p. 78-79. 
what has been read; speak effectively to various listeners, various goals, and know how to speak in a simple, eloquent, persuasive, or passionate manner at the right times; write effectively, understand and apply the rules of grammar, spelling, punctuation, and use effective vocabulary; show the ability to learn other languages; using listening, speaking, writing and reading skills to remember, communicate, discuss, explain, influence, create knowledge, compile meaning, and describe the language itself; trying to remind the use of his own language; show interest in journalism, poetry, storytelling, debate, speaking, writing or editing; creating new language forms or original writing or oral communication.

According to Yuliani ${ }^{8}$ there are several objectives to develop linguistic intelligence for teachers, namely; able to communicate both orally and in writing well; have language skills to convince others; able to remember and memorize others; able to provide an explanation; able to discuss the language itself. Based on this, it can be asserted that linguistic intelligence is the ability to use language and words, both written and oral, in various different forms to express their ideas. This linguistic intelligence is professionalized into several indicators, namely; hear and respond to every sound, rhythm, color and various word expressions; imitate voice, language, reading, and writing from other people; learning through listening, reading, writing and discussion; listen effectively, understand, describe, interpret and remember what is said; read effectively, understand, summarize, interpret or explain, and remember what has been read; speak effectively to various listeners, various goals, and know how to speak in a simple, eloquent, persuasive, or passionate manner at the right times; write effectively, understand and apply the rules of grammar, spelling, punctuation, and use effective vocabulary; show the ability to learn other languages; using listening, speaking, writing and reading skills to remember, communicate, discuss, explain, influence, create knowledge, compile meaning, and describe the language itself; trying to remind the use of his own language; show interest in journalism, poetry, storytelling, debate, speaking, writing or editing; creating new language forms or original writing or oral communication.

Emotional intelligence is the ability to feel. The key to emotional intelligence is in human honesty in conscience. That conscience should be the center of a principle that can provide security, guidance, strength and wisdom. This emotional intelligence is built on six principles based on 6 Pillars of Faith starting from; star principle, angel principle, leadership principle, learning principle, vision principle, and well organized principle. In this section there will be a format of emotional intelligence based on spiritual awareness and in accordance with the deepest conscience of the human being (self conscience). ${ }^{9}$

'Yuliani, "Kecerdasan Linguistik Guru dalam Pembelajaran," in Jurnal Pendidikan Bahasa, Vol. 4, No. 2, 2011, p. 35-48.

${ }^{9}$ Ary Ginanjar Agustian, Rahasia Sukses Membangun Kecerdasan Emosi dan Spiritual ESQ: Emotional Spiritual Quationt Berdasarkan 6 Rukun Iman dan 5 Rukun Islam (Jakarta: Arga Wijaya Persada, 2007), p. 126-129. Daniel Goleman, Kecerdasan Emosional (Jakarta: Gramedia Pustaka Utama, 2001), p. 98. 
Based on this, it can be emphasized here that what is meant by emotional intelligence is the ability of a person to manage the emotions of themselves and others around them by recognizing and managing their own emotions, motivating themselves, recognizing the emotions of others, and building relationships with other people. To measure the stage of emotional intelligence in the teacher of the madrasah tsanawiyah, this term is operationalized with the following domains: ${ }^{10}$ First, managing one's emotions, which consists of self-perception, and self-sensitivity. Second, managing one's emotions, which consists of self-control, adaptability, and innovation. Third, motivate yourself, namely the drive for achievement, commitment, initiative, hope, and optimism. Fourth, recognize the emotions of others, namely understanding non-verbal messages, violations, and moral beliefs. Fifth, establish relationships with other people, namely display manners, mood synchronization, and social skills. Sixth, the star principle, angel principle, leadership principle, learning principle, vision principle, and well organized principle.

The question and answer method is a way of teaching where a teacher asks a few questions to students about the material that has been taught or the reading material they have read while paying attention to the thinking process among students. ${ }^{11}$ Question and answer method is a way of presenting lessons in the form of questions that must be answered, especially from the teacher to students, but can also be from students to teachers. ${ }^{12}$ Question and answer method is a way of delivering material for learning Islamic education through the form of questions that must be answered by students both from Islamic religious education teachers and from the students themselves to achieve maximally determined learning competencies. ${ }^{13}$

The success of the teacher using the question and answer method can be measured by his ability to carry out the steps of this method. Thus there are a number of steps that must be considered by the teacher in carrying out the question and answer method in each Islamic religious education learning activity, ${ }^{14}$ namely: determine the learning objectives of the question and answer method through indicator analysis; managing students' attention; distribution of material; ask questions; There are several techniques that the teacher can use at this stage in using the question and answer method for the successful learning of Islamic religious education conducted, namely; (1) giving questions to students; (2) clarification

${ }^{10}$ Ary Ginanjar Agustian, Rahasia Sukses, p. 143.

${ }^{11}$ Ramayulis, Metodologi Pendidikan Agama Islam (Jakarta: Kalam Mulia 2010), p. 211. Zurinal Z \& Wahdi Sayuti, Ilmu Pendidikan Islam: Pengantar dan Dasar-dasar Pelaksanaan Pendidikan (Jakarta: Lembaga Penelitian UIN Jakarta bekerja sama dengan UIN Jakarta Press, 2006), p. 132.

${ }^{12}$ Syaiful Bahri Djamarah \& Aswan Zain, Strategi Belajar Mengajar (Jakarta: Rineka Cipta, 2002), p. 78.

${ }^{13}$ Syahraini Tambak, 6 Metode Komunikatif Pendidikan Agama Islam (Yogyakarta: Graha Ilmu, 2014), p. 78-92.

${ }^{14}$ Syahraini Tambak, 6 Metode Ilmiah dan Inovatif Pendidikan Agama Islam (Yogyakarta: Graha Ilmu, 2014), p. 132. 
of questions; (3) giving students time to think and compile answers; (4) asking students to answer questions; (5) redirecting; (6) providing guidance (prompting); (7) the teacher gives an answer. Sixth, make conclusions together. At this stage the things done by a PAI teacher can use crucial steps, namely; (1) asking students to give conclusions on the material taught starting from each learning indicator; (2) asking other students to complete the conclusions that have been stated by previous students; (3) the teacher and students classify the conclusions according to the learning indicators; and (4) asking students to write out an outline of the learning conclusions in accordance with the learning indicators on their working paper. Seventh, conduct an evaluation. After the conclusion, then the next is to evaluate the mastery of the material of students and also the successful use of the question and answer method implemented.

\section{Research Methodology}

This type of research is correlation ${ }^{15}$ which aims to explore the strengthening of linguistic intelligence and emotional intelligence in developing the use of the question and answer method of teachers in Pekanbaru City Madrasah Tsanawiyah. The research was carried out at the State Madrasah Tsanawiyah (MTsN) throughout Pekanbaru City, namely MTsN 1 Andalan Pekanbaru City, MTsN 2 Pekanbaru City, and MTsN 3 Pekanbaru City. The subjects of this study were teachers in the field of Fiqh study, Al-Qur'an Hadith, Akidah Akhlak, Islamic History of Islam, and Arabic in all State MTs throughout Pekanbaru City. The population in this study all teachers of State MTs throughout Pekanbaru City (3 Madrasah) totaled 126 , and were not sampled, so that all were studied universally.

Questionnaire is used as a data collection technique. Questionnaire is considered to be one of the right ways to get information from respondents. ${ }^{16}$-Questionnaire is a data collection technique that is done by giving a set of written questions to respondents to be answered. ${ }^{17}$ Questionnaires were given to all teachers who taught the field of Fiqh study, Al-Qur'an Hadith, Akidah Akhlak, Islamic History of Islam, and Arabic in the State MTs throughout the City of Pekanbaru. Questionnaire contains instruments compiled consisting of three parts, namely the scale of linguistic intelligence, emotional intelligence, and steps of the question and answer method. The linguistic intelligence scale is arranged based on twelve constructs, namely; hear and respond to every sound, rhythm, color and various word expressions; imitate voice, language, reading, and writing from other people; learning through listening,

\footnotetext{
${ }^{15}$ Sugiyono, Metode Penelitian Pendidikan (Pendekatan Kuantitatif, Kualitatif, dan R\&D) (Bandung: Alfabeta, 2014), p. 98; Anas Sudijono, Metode Penelitian Kombinasi (Bandung: Alfabeta, 2012), p. 156.

${ }^{16}$ Bruce W. Tuckman, Analyzing Social Education Research Data (London: McGraw Hill Book Co., 1978), p. 178-182.

${ }^{17}$ Sulaiman Ngah Razali, Analisis Data dalam Penyelidikan Pendidikan (Kuala Lumpur: Dewan Bahasa Pustaka, 1996), p. 182.
} 
reading, writing and discussion; listen effectively, understand, describe, interpret and remember what is said; read effectively, understand, summarize, interpret or explain, and remember what has been read; speak effectively to various listeners, various goals, and know how to speak in a simple, eloquent, persuasive, or passionate manner at the right times; write effectively, understand and apply the rules of grammar, spelling, punctuation, and use effective vocabulary; show the ability to learn other languages; using listening, speaking, writing and reading skills to remember, communicate, discuss, explain, influence, create knowledge, compile meaning, and describe the language itself; trying to remind the use of his own language; show interest in journalism, poetry, storytelling, debate, speaking, writing or editing; and creating new language forms or original writing or oral communication. Emotional intelligence scale is arranged based on six constructs, namely; recognize self emotions; managing one's emotions; motivate yourself; recognize the emotions of others; establish relationships with other people; and, the star principle, angel principle, leadership principle, learning principle, vision principle, and well organized principle. While the use of the question and answer method is based on seven constructs, namely; determine the learning objectives of the question and answer method through indicator analysis; manage the attention of students; distribution of material; explore students' understanding; asking question; make conclusions together; conduct an evaluation.

Data were analyzed using inference statistics. Inference statistical analysis is used to test hypotheses that have been fostered through linear regression tests $(\mathrm{p}<0.05) .{ }^{18}$ The hypothesis of this study is "there is an influence of linguistic intelligence and emotional intelligence on the development of teacher success using the question and answer method of Java in learning". Data were analyzed using Statistical Product Service Solution (SPSS) version 20 assistance.

\section{Result and Discussion}

\section{Result}

Table 1 illustrates that there is an influence of linguistic intelligence and emotional intelligence on the success of teachers using question and answer in the Pekanbaru City State Madrasah. This is marked by the Annova test where the value of Sig is 0.001 ( $p<0.05)$ and $F$ value is (7.130). This finding illustrates that the hypothesis that there is an influence of linguistic intelligence and emotional intelligence on the success of the teacher using the question and answer method of teachers in the State Islamic Madrasah of Pekanbaru City is accepted.

${ }^{18}$ Sugiyono, Metode Penelitian Pendidikan, p. 78. 
MIQOT Vol. 43 No. 1 Januari-Juni 2019

Table 1: Annova

\begin{tabular}{llcccc}
\hline \multicolumn{1}{c}{ Model } & Sum of Squares & Df & Mean Square & F & Sig. \\
\hline Regression & 214.419 & 2 & 107.215 & 7.130 & $.001^{\text {b }}$ \\
1 Residual & 917.708 & 63 & 14.548 & & \\
Total & 1232.218 & 65 & & & \\
\hline
\end{tabular}

a. Dependent Variable: Use of the Question and Answer Method

b. Predictors: (Constant), Linguistic Intelligence, Emotional Intelligence

Furthermore it is clearly illustrated in table 2 strong relationship (value $r=0.761$ ) linguistic intelligence and emotional intelligence with the use of the question and answer method of the teacher of the madrasah tsanawiyah. Also seen is the contribution of linguistic intelligence and emotional intelligence to the success of teachers using the question and answer method, where the value of R Square (0.689) indicates a strong influence. The findings of this study illustrate that linguistic intelligence and emotional intelligence contribute strongly or $68.9 \%$ in developing teacher success using the question and answer method.

Table 2: Model Summary

\begin{tabular}{cccccc}
\hline Model & R & R Square & Adjusted R Square & $\begin{array}{c}\text { Std. Error of } \\
\text { the Estimate }\end{array}$ & Durbin-Watson \\
\hline 1 & $.761^{\mathrm{a}}$ & .579 & .164 & 3.817 & 1.987 \\
\hline a. Predictors: (Constant), Linguistic Intelligence, Emotional Intelligence \\
\hline b. Dependent Variable: Use of the Question and Answer Method \\
\hline
\end{tabular}

To see the contribution of each linguistic intelligence variable and emotional intelligence in building the ability of teachers of the Pekanbaru City State Madrasahs to use the question method in learning can be seen in table 3 . Table 3 illustrates that the successful use of the question and answer method implemented by madrasah tsanawiyah teachers without understanding linguistic intelligence and emotional intelligence is 26,508. However, if linguistic intelligence is attempted to be improved and owned by madrasah tsanawiyah teachers, it is predicted that it will contribute to the "medium" success using the question and answer method of 0.533 , and vice versa if there is a weakening of mastery of linguistic intelligence, it will experience a decrease in the use of question and answer methods. Another thing is that whenever the emotional intelligence is owned by the teacher and improved, it is predicted that there will be a "strong" contribution (0.655) in increasing the success of the teacher using the question and answer method. Likewise, on the contrary, whenever emotional intelligence is ignored, it is predicted that there will be a decrease in the success of the teacher using a question and answer method of 0.655 . 
Syahraini Tambak \& Desi Sukenti: Strengthening Linguistic and Emotional Intelligence

Table 3: Coefficients

\begin{tabular}{|c|c|c|c|c|c|c|c|c|}
\hline & \multirow[t]{2}{*}{ Model } & \multicolumn{2}{|c|}{$\begin{array}{l}\text { Unstandardized } \\
\text { Coefficients }\end{array}$} & \multirow{2}{*}{$\frac{\begin{array}{c}\text { Standardized } \\
\text { Coefficients }\end{array}}{\text { Beta }}$} & \multirow[t]{2}{*}{$\mathrm{T}$} & \multirow[t]{2}{*}{ Sig. } & \multicolumn{2}{|c|}{ Collinearity Statistics } \\
\hline & & B & Std. Error & & & & Tolerance & VIF \\
\hline & (Constant) & 26.508 & 8.843 & . & 2.998 & .004 & & \\
\hline 1 & $\begin{array}{l}\text { Linguistic } \\
\text { Intelligence }\end{array}$ & .533 & .065 & 059 & .512 & .611 & .969 & 1.032 \\
\hline & $\begin{array}{l}\text { Emotional } \\
\text { Intelligence }\end{array}$ & .655 & .119 & .442 & 3.833 & .000 & .969 & 1.032 \\
\hline
\end{tabular}

a. Dependent Variable: Use of the Question and Answer Method

Thus mastery of linguistic intelligence and emotional intelligence will be able to develop the success of madrasah tsanawiyah teachers using the question and answer method in learning. Linguistic intelligence is predicted to be able to develop the success of madrasah tsanawiyah teachers using the question and answer method, as well as emotional intelligence. It's just that emotional intelligence contributes higher than linguistic intelligence in developing the success of madrasah tsanawiyah teachers in using the question and answer method during learning.

\section{Discussion}

The results of this study found that linguistic intelligence and emotional intelligence simultaneously contributed strongly to developing teachers' abilities and success using the question and answer method in the learning process. Linguistic intelligence is predicted to be able to develop the success of madrasah tsanawiyah teachers in using question and answer methods, as well as emotional intelligence. Emotional intelligence contributes higher than linguistic intelligence in developing the success of madrasah tsanawiyah teachers in using question and answer methods during learning. The results of this study are consistent with the findings of the study which confirm that linguistic intelligence is able to develop methods of teaching teachers in carrying out learning in the world of education. ${ }^{19}$ The results of other studies found that linguistic intelligence must be owned by the teacher in the learning process, especially when using the question and answer method, so that students quickly understand the material being taught. ${ }^{20}$ Linguistic intelligence is able to strengthen the

${ }^{19}$ I. Irvaniyah, \& W Winarso, "Analisis Kecerdasan Logis Matematis dan Kecerdasan Linguistik Siswa Berdasarkan Jenis Kelamin," in Eduma, Vol. 2, No. 2, 2013, p. 96-113.

${ }^{20}$ N. H. Rofiah, "Menerapkan Multiple Intelligences dalam Pembelajaran di Sekolah Dasar," in Jurnal Dinamika Pendidikan Dasar, Vol. 8, No. 1, 2016, p. 69-79. 
ability of teachers in developing various methods used in the learning process and it has an impact on the development of linguistic intelligence of students. ${ }^{21}$

Linguistic intelligence is intelligence in processing words or the ability to use words effectively both verbally and in writing. People with high linguistic intelligence will be able to establish effective communication with others, able to speak well to those around them, able to develop harmonious relationships with others. Linguistic intelligence is also said to be the intelligence of word processing, meaning as a person's ability and skill in creating relationships and maintaining social relations so that both parties are in a mutually beneficial relationship. ${ }^{22}$ Linguistic intelligence is the ability in the field of language arts: speaking, writing, reading and listening. Linguistic intelligence, according Gadner ${ }^{23}$, is the ability to use language and words, both written and oral, in a variety of different forms to express ideas. Teachers with high linguistic intelligence are generally characterized by their pleasure in activities related to language use such as reading, writing, writing, making poetry, composing aphorisms.

The findings of this study are also in accordance with the results of Prasetyo ${ }^{24}$ research which states that emotional intelligence contributes greatly to improving employee performance in the era of globalization. In this connection, it can be interpreted that the teacher's performance using the question and answer method can increase with the strengthening and mastery of the teacher on emotional intelligence. Other research results also confirm that emotional intelligence is able to develop teacher performance in using learning methods well. ${ }^{25}$ Other studies have found that emotional intelligence possessed by teachers becomes the main support for the achievement of the use of learning methods to develop students' abilities. ${ }^{26}$ Research of Asyari ${ }^{27}$ revealed that teachers in using learning methods are required to be professional in behaving and being creative in shaping patterns of interaction that can encourage students to learn. While the formation of attitudes and creative power requires

${ }^{21}$ S. Widyawati, "Eksperimentasi Model Pembelajaran Student Facilitator and Explaining (SFE) terhadap Hasil Belajar ditinjau dari Kecerdasan Linguistik," in Al-Jabar: Jurnal Pendidikan Matematika, Vol. 7, No. 2, 2016, p. 267-274.

${ }^{22}$ Linda Campbell, Multiple Intelligences: Metode Terbaru Melesatkan Kecerdasan, p. 187. 78-123

${ }^{23}$ Howard Gadrner, Mulitiple Intelligence (Jakarta: Gramedia Pustaka Utama, 2018), p.

${ }^{24}$ H. D. Prasetyo, "Kecerdasan Emosional Dan Kecerdasan Spiritual Bersinergi dalam Meningkatkan Kepuasan Kerja dan Kinerja Karyawan PT. Bangun Papan Selaras," in Media Mahardika, Vol. 15, No. 2, 2017, p. 167-178.

${ }^{25}$ D. Herawaty, "Pengaruh Kecerdasan Emosional, Partisipasi Guru dalam Forum Ilmiah, Keyakinan Diri (Self Efficacy), dan Motivasi Kerja terhadap Kinerja Guru Matematika," in JRPM, Vol. 1, No. 1, 2016, p. 71-85.

${ }^{26}$ Citro, "Kecerdasan Emosional dan Kecerdasan Spiritual Meningkatkan Kompetensi Sosial Guru," in Jurnal Pendidikan dan Pembelajaran, Vol. 3, No. 6, 2014, p. 1-14.

${ }^{27}$ Akhmad Asyari, "Kecerdasan Emosional Meningkatkan Kreativitas Guru dalam Mengajar," in el-Hikmah: Jurnal Kajian dan Penelitian Pendidikan Islam, Vol. 10, No. 2, 2016, p. 179-188. 
emotional intelligence that can influence thoughts, feelings, responses, and manipulate information in establishing a harmonious relationship with students.

This study also found that if the mastery of teachers about linguistic intelligence is improved, it will provide moderate contribution to building the ability of teachers to use the question and answer method in learning. On the other hand, this study also found that if the mastery of teachers about emotional intelligence is improved it will provide a high contribution to building the ability of teachers of madrasah tsanawiyah to use the question and answer method in learning. This moderate increase occurred because it was in accordance with Amalia study that the content contained in the indicators of linguistic intelligence was only partially internalized by the teacher when learning took place. The language skills that they have had are considered adequate so that they contribute to developing the creativity of teachers in the learning process. The results of Yaumi ${ }^{28}$ research found that the linguistic intelligence possessed by the teacher was not fully explored so that the internalization of its values only went according to the influence of the environment so that the ability of the teacher's performance to use the method was not too maximal, but had an impact.

The findings of this study are corroborated by research conducted by Kim H. Song and Jack D. Simons which states that linguistic intelligence strengthens the teacher's pedagogical competency abilities, elicits teaching motivation, teacher language skills, and teacher teaching behavior in the process of becoming a professional teacher. At this stage linguistic intelligence will facilitate the use of teacher teaching methods so that they will easily teach and explore the abilities of students. ${ }^{29}$ Hasbi Sjamsir's research reinforces the findings of this study that linguistic intelligence is able to encourage successful teachers to use a learning method. Linguistic intelligence not only helps teachers become proficient in using learning methods but is proficient in building language skills so that students easily master the learning material being taught. The ability of linguistic intelligence is very crucial for teachers in manifesting themselves into professionals. ${ }^{30}$

In various studies it was found that linguistic intelligence also contributed to an increase in various activities both for teachers and students. The findings of Swasti, Candiasa, \& Warpala ${ }^{31}$ in his research that linguistic intelligence is able to contribute significantly

${ }^{28}$ Muhammad Yaumi, "Desain Strategi Pembelajaran untuk Mengembangkan Kecerdasan Linguistik Peserta Didik," in Auladuna: Jurnal Pendidikan Dasar Islam, Vol. 2, No. 2, 2016, p. 185-200.

${ }^{29} \mathrm{Kim}$ H. Song and Jack D. Simons, "Beyond Gardner: A Pilot Case Study Assesing Teachers' Linguistic Intelligence," in Nys Tesol Journal, Vol. No. 1, 2014, p. 66-81.

${ }^{30}$ Hasbi Sjamsir, "The Influence of Tpr, Gtm Methods and Linguistic Intelligence Toward the Learning Outcomes in English Dap Based (An Experimental Study at the Students of the Second Grade of Sdn Samarinda, East Borneo)," in English Literature and Language Review, Vol. 4, No. 4, 2018, p. 58-61.

${ }^{31}$ N. M. Swasti, I Made Candiasa, W. S. Warpala, "Pengaruh Model Pembelajaran Kontekstual dan Kecerdasan Linguistik terhadap Keterampilan Menulis dalam Bahasa Inggris bagi Siswa Kelas X di SMK Negeri Abang," in Jurnal Teknologi Pembelajaran, Vol. 3, No. 2, 2013, p. 175-192. 
(medium) in developing students' language skills when learning takes place. This is also associated with the teacher's creativity in teaching so it is possible to have an impact on the teacher's ability to develop a question and answer method. In the Novianti's ${ }^{32}$ study found that linguistic intelligence has a significant impact in developing the beginning of reading skills. In this study linguistic intelligence can develop together with the use of good learning methods. So for the teacher, this can improve the ability to use the question and answer method.

While emotional intelligence is predicted to provide a high increase in the use of the question and answer method, it occurs because, in accordance with Nasir's ${ }^{33}$, research findings, the values of emotional intelligence are the main determinants of improving the professionalism of madrasah teachers, including using learning methods such as the question method answer, lecture, and others. According to Masdudi's ${ }^{34}$ study if the emotional intelligence possessed by a teacher is improved then it can encourage a high increase in the ability of the teacher to use the method. This can simultaneously encourage students to do quality learning so that the learning objectives can be achieved optimally. Therefore, madrasah teachers are required to have high emotional intelligence so that it can lure students to develop their inhibitory attitudes in learning.

In the Asyari ${ }^{35}$ research strengthens this research that if a madrasah teacher increases the mastery of emotional intelligence from him, it will increase the ability and creativity in using the method when learning, one of which is the question and answer method. Fatwa $\&$ Diah $^{36}$ research states that teachers who manage emotional intelligence will have a crucial impact on commitment in carrying out teacher tasks in the learning process. One important task to be held firm is to use the correct question and answer method in learning.

The term "emotional intelligence" was first raised in 1990 by psychologists Peter Salovey of Harvard University and John Mayer of the University of New Hampshire to explain emotional qualities that seem important to success. After Peter Slovey and John Mayer came up with this term, Daniel Goleman then developed it in 1995 with the theory of emotional intelligence. In various studies he did he insisted that one's success in life could not only be with a high IQ, there were other factors that would support that success. Goleman considers

${ }^{32}$ Rahmah Novianti, "Pengaruh Permainan Kartu Bergambar dan Kecerdasan Linguistik terhadap Kemamapuan Membaca Permulaan," in Jurnal Pendidikan Usia Dini, Vol. 7, No. 2, 2013, p. 192-210.

${ }^{33} \mathrm{M}$. Nasir, "Profesionalisme Guru Agama Islam: Sebuah Upaya Peningkatan Mutu melalui LPTK," in Dinamika Ilmu: Journal of Education, Vol. 13, No. 2, 2013, p. 189-203.

${ }^{34}$ Masdudi, "Pengembangan Kecerdasan Emosional Guru PAUD dalam Proses Pembelajaran," in Awlady Jurnal Pendidikan Anak, Vol. 2, No. 1, 2016, p. 78-89.

${ }^{35}$ Akhmad Asyari, "Kecerdasan Emosional Meningkatkan Kreativitas Guru dalam Mengajar," in el-Hikmah: Jurnal Kajian dan Penelitian Pendidikan Islam, Vol. 10, No. 2, 2016, p. 179-188.

${ }^{36}$ Sakinah Fatwa \& Andi Diah, "Pengaruh Kepemimpinan, Kecerdasan Emosional, dan Efikasi Diri terhadap Komitmen Tugas pada Guru SMAT PKP Jakarta Islamic School," in Edukasi Islami: Jurnal Pendidikan Islam, Vol. 7, No. 2, 2015, p. 145-161. 
that IQ is not a genetic fact that cannot be changed by life experience and human destiny in life is not only influenced by this factor. For example, what can be changed to help children have a better life? Which factors are more important, for example when people with high IQ fail and people with average IQ are very successful? Goleman said that the difference lies in emotional intelligence abilities which include self-control, enthusiasm and perseverance, and the ability to motivate yourself. ${ }^{37}$

Above capabilities are also called skills, in the view of Goleman ${ }^{38}$ can be taught to children to provide better opportunities for the success of their lives. Someone who wants to succeed in life cannot only rely on high IQ, because in his research, Goleman stated that intellectual intelligence (IQ) only contributes $20 \%$ to factors that determine success in life, while $80 \%$ is filled by other forces . These factors are the ability to motivate yourself and endure frustration, control impulses and not exaggerate pleasure, maintain moods and keep the burden of stress from paralyzing the ability to think, empathize and pray. According to Sunar ${ }^{39}$ emotional intelligence is the ability of a person to receive, assess, manage, and control the emotions of himself and others around him. Shapiro ${ }^{40}$ defines emotional intelligence as a subset of social intelligence that involves the ability to monitor social feelings that involve abilities in others, sorting through all of them and using this information to guide thoughts and actions. Nata (2003) views emotional intelligence as expertise, intelligence, and determination of a person in managing themselves in dealing with others around them by using all the psychological potential they have, such as initiative and empathy, adaptation, communication, cooperation, and persuasion abilities.

Agustian $^{41}$ a figure who invented emotional and spiritual intelligence said that emotional independence was the ability to feel. The key to emotional intelligence is in human honesty in conscience. That conscience should be the center of a principle that can provide security, guidance, strength and wisdom. This emotional intelligence is built on six principles based on 6 Pillars of Faith starting from; star principle, angel principle, leadership principle, learning principle, vision principle, and well organized principle.

Gardner, as quoted by Goleman ${ }^{42}$ says that not only is one type of monolithic intelligence important for success in life, but there is a wide intelligence spectrum with seven main varieties namely linguistics, mathematics/logic, spatial, kinesthetic, music, interpersonal and intrapersonal. This intelligence is named by Gardner as personal intelligence which Goleman calls emotional intelligence. According to Gardner, personal intelligence consists of "interpersonal intelligence,

${ }^{37}$ Daniel Goleman, Kecerdasan Emosional, p. 132.

${ }^{38}$ Ibid., p. 123.

${ }^{39}$ Dwi Sunar, Edisi Lengkap Tes IQ, EQ, dan SQ (Yogyakarta: FlashBooks. 2001), p. 45.

${ }^{40}$ Lawrence E. Shapiro, Mengajarkan Emotional Intelligence pada Anak (Jakarta: Gramedia Pustaka Utama, 2003), p. 154.

${ }^{41}$ Ary Ginanjar Agustian, Rahasia Sukses, p. 134.

${ }^{42}$ Goleman, Kecerdasan Emosional, p. 133. 
namely the ability to understand others, what motivates them, how they work, how to work hand in hand with intelligence. Whereas intra-personal intelligence is a correlative ability, but directed inwardly. This ability is the ability to form a self-model that is rigorous and refers to oneself and the ability to use that capital as a tool to lead life effectively. ${ }^{43}$

Emotional intelligence is a person's ability to manage themselves in dealing with others around them by using all the psychological potential they have with self-control, enthusiasm and perseverance, motivating themselves and enduring frustration, controlling impulses and not exaggerating pleasure, maintaining the mood and keeping the stress burden from paralyzing the ability to think, empathize and pray. This emotional intelligence consists of; managing self emotions, which consists of self-perception, and self-sensitivity; managing self emotions, which consists of self-control, adaptability, and innovation; motivate yourself, namely the drive for achievement, commitment, initiative, hope, and optimism; and recognize other people's emotions, namely understanding nonverbal messages, violations, and moral beliefs. ${ }^{44}$

Other research states that the components in the construct of emotional intelligence will be able to increase one's productivity at work. ${ }^{45}$ If this research is related to the teacher's performance, it proves that teacher productivity in using the question and answer method will increase if emotional intelligence is controlled maximally. The results of this study also reinforce research which states that the performance of an employee will increase if emotional intelligence is in him. ${ }^{46}$ The teacher's performance can be explained by various things related to the implementation of learning activities in Islamic education institutions, one of which is the use of the lecture method in the learning process. This was as stated by Sudirman and Bokingo ${ }^{47}$ that the teacher's performance included pedagogic competencies, one of which was skilled in using learning methods. This confirms that emotional intelligence will have an impact on improving teacher performance using the method of answering the learning process.

${ }^{43}$ Ibid., p. 136.

${ }^{44}$ Ibid., p. 136.

${ }^{45}$ A. Gustina Zainal \& A. Saleh, "Pengaruh Kecerdasan Emosional dan Motivasi terhadap Kinerja Penyuluh di Dinas Pertanian Kabupaten Tanggamus," in Profetik Jurnal Komunikasi, Vol. 10, No. 2, 2017, p. 69-79. Syahraini Tambak, \& Desi Sukenti, "Implementasi Budaya Melayu dalam Pendidikan Madrasah Ibtidaiyah di Riau," in MIQOT: Jurnal Ilmu-Ilmu Keislaman, Vol. 41, No. 2, 2017, p. 361-383.

${ }^{46} \mathrm{~A}$. Choiriah, "Pengaruh Kecerdasan Emosional, Kecerdasan Intelektual, Kecerdasan Spiritual, dan Etika Profesi terhadap Kinerja Auditor dalam Akuntan Publik," in Jurnal Akuntansi, Vol. 4, No. 1, 2013, p. 101-124.

${ }^{47}$ Sudirman \& Agus Hakri Bukingo, "Kinerja Guru Pasca Sertifikasi," in Jurnal Perspektif Ilmu Pendidikan, 13 (2), 2017, p. 98-104; Amiruddin Siahaan, "Profesionalitas Guru Menurut M. Quraish Shihab dalam Tafsir al-Misbah," in MIQOT: Jurnal Ilmu-Ilmu Keislaman, Vol. XI, No. 2, 2016, p. 308-327. 
Other research results also state that emotional intelligence can improve one's learning outcomes. ${ }^{48}$ This proves that mastery of emotional intelligence in various fields including learning outcomes of students can improve, and this is certainly also the case with someone's work. Likewise with the teacher, if you master emotional intelligence on an on going basis it will develop the teacher's ability to use the question and answer method in learning. The question and answer method is a way of presenting the lesson in the form of questions, which are expressed by the teacher that must be answered by students. ${ }^{49}$ Historically this method includes the oldest method. Socrates, who lived in 465-399 BC, for example, has used this question and answer method in developing his philosophical thinking and in teaching it to Greek society at that time. This method motivates students to ask questions during the teaching and learning process, or the teacher who asks questions and students who answer. The contents of the question must always be related to possible learning material that can be expanded in general. ${ }^{50}$

In Fitriani, Asy'ari, Zubaidah, and Mahanal's research, it was revealed that emotional intelligence has an impact on critical thinking attitude for teachers in teaching. Critical thinking of teachers in analyzing learning material is very helpful for students to use reason to analyze learning material. ${ }^{51}$ Research by Sjaifuddin, Hidayat, Fathurrohman, Ardie, \& El Islami also revealed that the ability of a teacher to manage themselves optimally is very helpful for self-development in the learning approach process. The learning method used by strengthening self-emotion greatly helps the teacher's success in teaching. That is why the teaching approach is very important to be mastered by the teacher and it starts with maximum self-management. ${ }^{52}$

The question and answer method is a way of presenting teaching by the teacher by giving questions and asking students for answers. If this understanding is related to Islamic religious education then it can be understood that the question and answer method is the presentation of Islamic religious education teaching in which Islamic religious education teachers provide a number of questions in accordance with the indicators and learning objectives and ask students to answer. ${ }^{53}$

${ }^{48} \mathrm{~V}$. Rosida, "Pengaruh Kecerdasan Emosional terhadap Hasil Belajar Matematika Siswa Kelas VII 2 SMP Negeri 1 Makassar," in Jurnal Sainsmat, Vol. 4, No. 2, 2015, p. 87-101.

${ }^{49}$ Abuddin Nata, Manajemen Pendidikan, Mengatasi Kelemahan Pendidikan Islam (Jakarta: Kencana: 2003), p. 154.

${ }^{50}$ Syaiful Bahri Djamarah \& Aswan Zain, Strategi Belajar Mengajar, p. 156.

${ }^{51}$ H. Fitriani, M. Asy'ari, S. Zubaidah, \& S. Mahanal, "Exploring the Prospective Teachers' Critical Thinking and Critical Analysis Skills," in Jurnal Pendidikan IPA Indonesia, Vol. 8, No. 3, 2019, p. 379-390.

${ }^{52}$ S. Sjaifuddin, S. Hidayat, M. Fathurrohman, R. Ardie, \& R. A. Z. El Islami, “The Development of Food Security Behavior Model through Environmental-Based Learning: A System Dynamics Approach," in Jurnal Pendidikan IPA Indonesia, Vol. 8, No. 2, 2019, p. 230-240

${ }^{53}$ Darwyan Syah, Strategi Pembelajaran Pendidikan Agama Islam (Jakarta: Faza Media, 2006), p. 76. 
The question and answer method can stimulate students to express their opinions and thoughts. Through the questions posed by Islamic religious education teachers, students are encouraged to find the right and satisfying answers by assembling the knowledge they already have. If the knowledge possessed is inadequate to answer the questions posed by the teacher, students will be aroused and challenged to explore the answers data in various appropriate ways by reading, researching or research in the laboratory. ${ }^{54}$

\section{Conclusion}

This study found that linguistic intelligence and emotional intelligence contributed strongly to developing the teacher's ability to use the question and answer method in the learning process. The success of the teacher using the question and answer method without being followed by mastery and strengthening of linguistic intelligence and emotional intelligence is low. The mastery of teachers about improved linguistic intelligence will provide a moderate contribution to the contribution, while emotional intelligence has a high contribution to building the ability of the teacher of the madrasah tsanawiyah using the question and answer method in learning. Emotional intelligence has a higher contribution compared to linguistic intelligence in building the ability of teachers to use the question and answer method.

This study contributes in developing the formulation of lecture material in the PAI Learning Method subject. For lecturers, the PAI Learning Method in the Islamic Education Program (PAI) can be an important contribution in preparing the syllabus, SAP and the development of lecture materials so that students can have good competence in the process of becoming a professional teacher. For teachers of Madrasah Tsanawiyah, this research can contribute to improving the quality of use of the teacher question and answer method by strengthening linguistic intelligence and emotional intelligence in the learning process.

\section{References}

Agustian, Ary Ginanjar. Rahasia Sukses Membangun Kecerdasan Emosi dan Spiritual ESQ: Emotional Spiritual Quationt Berdasarkan 6 Rukun Iman dan 5 Rukun Islam. Jakarta: Arga Wijaya Persada, 2007.

Amalia, Taranindya Zulhi. "Internalisasi Peningkatan Linguistik Verbal Melalui Muatan Kurikulum Pembelajaran Bahasa Inggris PAUD," in Thufula: Jurnal Inovasi Pendidikan Guru Raudhatul Athfal, Vol. 4, No. 2, 2016.

Asrul dan Ja'far (ed.). Falsafah Pendidikan Islami: Menguak Nilai-nilai Pendidikan dalam Tradisi Islam. Medan: Perdana Publishing, 2016.

Asyari, Akhmad. "Kecerdasan Emosional Meningkatkan Kreativitas Guru dalam Mengajar," in el-Hikmah: Jurnal Kajian dan Penelitian Pendidikan Islam, Vol. 10, No. 2, 2016.

${ }^{54}$ Ibid., p. 77. 
Ahmad, M. Yusuf \& Syahraini Tambak. "Penerapan Metode Diskusi dalam Meningkatkan Hasil Belajar Murid pada Pelajaran Fiqh," in Al-Hikmah: Jurnal Agama dan Ilmu Pengetahuan, Vol. 5, No. 1, 2018.

Arief, Armai. Pengantar dan Metodologi Pendidikan Islam. Jakarta: Ciputat Pers, 2002.

Campbell, Linda. Multiple Intelligences: Metode Terbaru Melesatkan Kecerdasan. Depok: Inisiasi Press, 2002.

Choiriah, A. "Pengaruh Kecerdasan Emosional, Kecerdasan Intelektual, Kecerdasan Spiritual, dan Etika Profesi terhadap Kinerja Auditor dalam Akuntan Publik," in Jurnal Akuntansi, Vol 4, No. 1, 2013.

Citro. "Kecerdasan Emosional dan Kecerdasan Spiritual Meningkatkan Kompetensi Sosial Guru," in Jurnal Pendidikan dan Pembelajaran, Vol. 3, No. 6, 2014.

Daradjat, Zakiah. Metodik Khusus Pembelajaran Agama Islam. Jakarta: Bumi Aksara, 1995.

Djamarah, Syaiful Bahri \& Aswan Zain. Strategi Belajar Mengajar. Jakarta: Rineka Cipta, 2002.

Fatwa, Sakinah \& Andi Diah. "Pengaruh Kepemimpinan, Kecerdasan Emosional, dan Efikasi Diri terhadap Komitmen Tugas pada Guru SMAT PKP Jakarta Islamic School," in Edukasi Islami: Jurnal Pendidikan Islam, Vol. 7, No. 2, 2015.

Fitriani, H, M. Asy'ari, S. Zubaidah, \& S. Mahanal. "Exploring the Prospective Teachers' Critical Thinking and Critical Analysis Skills," in Jurnal Pendidikan IPA Indonesia, Vol. 8, No. 3, 2019.

Gadrner, Howard. Mulitiple Intelligence. Jakarta: Gramedia Pustaka Utama, 2018.

Ginting, Siti Aisyah. "A Facilitating Effective Teaching Through Learning Based on Learning Styles and Ways of Thinking," in Dinamika Ilmu: Journal of Education, Vol. 17, No. 2, 2017.

Goleman, Daniel. Kecerdasan Emosional. Jakarta: Gramedia Pustaka Utama, 2001.

Gustina Zainal, A., \& A. Saleh. "Pengaruh Kecerdasan Emosional dan Motivasi terhadap Kinerja Penyuluh di Dinas Pertanian Kabupaten Tanggamus," in Profetik Jurnal Komunikasi, Vol. 10, No. 2, 2017.

H. Song, Kim, and Jack D. Simons. "Beyond Gardner: A Pilot Case Study Assesing Teachers' Linguistic Intelligence," in Nys Tesol Journal, Vol. No. 1, 2014.

Herawaty, D. "Pengaruh Kecerdasan Emosional, Partisipasi Guru dalam Forum Ilmiah, Keyakinan Diri (Self Efficacy), dan Motivasi Kerja terhadap Kinerja Guru Matematika," in JRPM, Vol. 1, No. 1, 2016.

Helmi, Jon. "Penerapan Konsep Silberman dalam Metode Tanya Jawab pada Pembelajaran Pendidikan Agama Islam," in Al-Ishlah: Jurnal Pendidikan, Vol. 8, No. 2, 2016.

Irvaniyah, I., \& W. Winarso. "Analisis Kecerdasan Logis Matematis dan Kecerdasan Linguistik Siswa Berdasarkan Jenis Kelamin," in Eduma, Vol. 2, No. 2, 2013.

Masdudi. "Pengembangan Kecerdasan Emosional Guru PAUD dalam Proses Pembelajaran," in Awlady Jurnal Pendidikan Anak, Vol. 2, No. 1, 2016. 
Nasir, M. "Profesionalisme Guru Agama Islam: Sebuah Upaya Peningkatan Mutu melalui LPTK," in Dinamika Ilmu: Journal of Education, Vol. 13, No. 2, 2013.

Nata, Abuddin. Perspektif Islam tentang Strategi Pembelajaran. Jakarta: Kencana Prenada Media Group, 2011.

Nata, Abuddin. Manajemen Pendidikan, Mengatasi Kelemahan Pendidikan Islam. Jakarta: Kencana, 2003.

Novianti, Rahmah. "Pengaruh Peermainan Kartu Bergambar dan Kecerdasan Linguistik terhadap Kemampuan Membaca Permulaan," in Jurnal Pendidikan Usia Dini, Vol. 7, No. 2, 2013.

Prasetyo, H. D. "Kecerdasan Emosional dan Kecerdasan Spiritual Bersinergi dalam Meningkatkan Kepuasan Kerja dan Kinerja Karyawan PT. Bangun Papan Selaras," in Media Mahardika, Vol. 15, No. 2, 2017.

Purnama, I. M. "Pengaruh Kecerdasan Emosional dan Minat Belajar terhadap Prestasi Belajar Matematika di SMAN Jakarta Selatan," in Jurnal Formatif, Vol. 6, No. 3, 2016.

Ramayulis. Metodologi Pendidikan Agama Islam. Jakarta: Kalam Mulia, 2010.

Razali, Sulaiman Ngah. Analisis Data dalam Penyelidikan Pendidikan. Kuala Lumpur: Dewan Bahasa Pustaka, 1996.

Rofiah, N. H. "Menerapkan Multiple Intelligences dalam Pembelajaran di Sekolah Dasar," in Jurnal Dinamika Pendidikan Dasar, Vol. 8, No. 1, 2016.

Rosida, V. "Pengaruh Kecerdasan Emosional terhadap Hasil Belajar Matematika Siswa Kelas VII 2 SMP Negeri 1 Makassar," in Jurnal Sainsmat, Vol. 4, No. 2, 2015.

Satriani. "Inovasi Pendidikan: Metode Pembelajaran Monoton ke Pembelajaran Variatif (Metode Tanya Jawab Plus)," in Jurnal Pendidikan Islam Iqra', Vol. 10, No. 1, 2016.

Shapiro, Lawrence E. Mengajarkan Emotional Intelligence pada Anak. Jakarta: Gramedia Pustaka Utama, 2003.

Siahaan, Amiruddin. "Profesionalitas Guru Menurut M. Quraish Shihab dalam Tafsir alMisbah," in MIQOT: Jurnal Ilmu-Ilmu Keislaman, Vol. XI, No. 2, 2016.

Sjaifuddin, S., S. Hidayat, M. Fathurrohman, R. Ardie, \& R. A. Z. El Islami. "The Development of Food Security Behavior Model through Environmental-Based Learning: A System Dynamics Approach," in Jurnal Pendidikan IPA Indonesia, Vol. 8, No. 2, 2019.

Sjamsir, Hasbi. “The Influence of Tpr, Gtm Methods and Linguistic Intelligence Toward the Learning Outcomes in English Dap Based (An Experimental Study at the Students of the Second Grade of Sdn Samarinda, East Borneo)," in English Literature and Language Review, Vol. 4, No. 4, 2018.

Sudijono, Anas. Metode Penelitian Kombinasi. Bandung: Alfabeta, 2012.

Sudirman \& Agus Hakri Bukingo, "Kinerja Guru Pasca Sertifikasi," in Jurnal Perspektif Ilmu Pendidikan, Vol. 13, No. 2, 2017. 
Sugiyono. Metode Penelitian Pendidikan (Pendekatan Kuantitatif, Kualitatif, dan R\&D). Bandung: Alfabeta, 2014.

Sunar, Dwi. Edisi Lengkap Tes IQ, EQ, dan SQ. Yogyakarta: FlashBooks, 2010.

Swasti, N.M., I Made Candiasa, W.S. Warpala. "Pengaruh Model Pembelajaran Kontekstual dan Kecerdasan Linguistik terhadap Keterampilan Menulis dalam Bahasa Inggris bagi Siswa Kelas X di SMK Negeri Abang," in Jurnal Teknologi Pembelajaran, Vol. 3, No. 2, 2013.

Syah, Darwyan. Strategi Pembelajaran Pendidikan Agama Islam. Jakarta: Faza Media, 2006.

Tafsir, Ahmad. Metodologi Pembelajaran Agama Islam. Bandung: Remaja Rosdakarya, 2003.

Tambak, Syahraini. "Eksistensi Pendidikan Islam Al-Azhar: Sejarah Sosial Kelembagaan al-Azhar dan Pengaruhnya terhadap Kemajuan Pendidikan Islam Era Modernisasi di Mesir," in Al-Thariqah: Jurnal Pendidikan Agama Islam, Vol. 1, No. 2, 2016.

Tambak, Syahraini. Pendidikan Agama Islam: Konsep Metode Pembelajaran PAI. Yogyakarta: Graha Ilmu, 2014.

Tambak, Syahraini. 6 Metode Komunikatif Pendidikan Agama Islam. Yogyakarta: Graha Ilmu, 2014.

Tambak, Syahraini \& Desi Sukenti. "Implementasi Budaya Melayu dalam Pendidikan Madrasah Ibtidaiyah di Riau," in MIQOT: Jurnal Ilmu-Ilmu Keislaman, Vol. 41, No. 2,2017

Tuckman, Bruce W. Analyzing Social Education Research Data. London: McGraw Hill Book Co., 1978.

Yuliani. "Kecerdasan Linguistik Guru dalam Pembelajaran," in Jurnal Pendidikan Bahasa, Vol. 4, No. 2, 2013

Widyawati, S. "Eksperimentasi Model Pembelajaran Student Facilitator and Explaining (SFE) terhadap Hasil Belajar ditinjau dari Kecerdasan Linguistik," in Al-Jabar: Jurnal Pendidikan Matematika, Vol. 7, No. 2, 2016.

Yaumi, Muhammad. "Desain Strategi Pembelajaran untuk Mengembangkan Kecerdasan Linguistik Peserta Didik," in Auladuna: Jurnal Pendidikan Dasar Islam, Vol. 2, No. 2, 2015.

Zurinal \& Wahdi Sayuti. Ilmu Pendidikan Islam: Pengantar dan Dasar-dasar Pelaksanaan Pendidikan. Jakarta: Lembaga Penelitian UIN Jakarta bekerja sama dengan UIN Jakarta Press, 2006. 